\title{
Opera viewpoint a case for more funding
}

Since the disbanding of the last national company, opera in New Zealand has been underfunded and virtually relegated to the sidelines as an artistic activity. But, as Lindis Taylor, editor of Opera News, points out, regional opera has now acquired a new strength and vitality. In the light of a forthcoming review by the QEII Arts Council of their opera policy, he gives here a succinct background to these discussions.

\section{LINDIS TAYLOR}

Is there a link between the perception of the importance of events, historical developments, artistic genres and the existence of books about them? Certainly the appearance of two most important publications on New Zealand music within weeks of each other, Adrienne Simpson's Opera in New Zealand and J.M.Thomson's Oxford History of New Zealand Music must alter our view of the vital role of music in New Zealand life. New Zealand is unusual because the tradition of opera that existed in the 19th century and that continued through sporadic touring companies until after World War Two was forgotten and unchronicled. These books must now make it impossible for the QEII Arts Council to adhere to an extraordinary policy that has denied the relevance of opera here, funding it in so miserly a fashion for the past decade or more.

Although a detailed account of opera remains to be written there is an urgent need for the chronicling of the period from the end of World War Two following the founding of Donald Munro's New Zealand Opera Company in 1953. The company survived at first through mounting chamber opera, employing resident singers and by adroit management. After money began to come from the Arts Advisory Council it became bolder, leading to a famous Porgy and Bess, a fine Marriage of Figaro, substantial Verdi, a few contemporary pieces and even David Farquhar's A Unicorn for Christmas.

But state support proved a Trojan Horse, for the company was vulnerable to personal animosities and malice that destroyed the almost twenty-year-old organisation, the like of which has not been seen since. In the following two decades opera has rebuilt cautiously with local companies and an attempt to re-establish a national one based in Auckland. This was again wrecked through the performance of non-mainstream operas without the assurance of underwriting guarantees. Now there have been seven years of so-called regional opera. But while these companies have gained strength and experience they have learned to be cautious towards the innate capriciousness and arrogance of an arts bureaucracy and for the most part have been treated shabbily by it. Companies have learned, however, to hustle for commercial funds.

The price has been an inability to venture from works that are both familiar and musically accessible. Adequate houses can now be assured only by the repeated ploughing of a limited field. Unknown operas cannot support normal production costs without underwriting guarantees. Is this not the role of the Arts Council?

But the Arts Council's funding of opera has remained minuscule; furthermore, most of it has gone to Auckland's Mercury Theatre. For the Council remained the prisoner of its notion of a national opera company and of its conviction that the companies that have arisen in the southern cities have no substance. From 1988 the Council began to subsidise the other three companies with $\$ 40,000$ each per annum whereas Mercury's grant remained twice as much as the others put together at $\$ 275,000$. Yet each company produced two operas a year. In 1991 Wellington City Opera mounted three, with a grant increased pro rata to $\$ 108,000$, whereas Mercury's stood at $\$ 315,500$ for two, plus a joint production with the new Auckland Metropolitan Opera Company. The other companies stress that they do not seek any of the funds now going to Auckland but that the total money for opera should be increased greatly and that they should at least receive comparable treatment. Detailed examination of the costings show that no rational criteria can justify the present discrepancy. With productions as fine as $I l$ Trovatore in Wellington and La Traviata in Christchurch it is absurd to talk of regional opera as second rate.

An Opera Conference study has shown that Arts Council funds contributed $22 \%$ of average production costs for the last five years, and that the 1991 opera budget of $\$ 530,000$, or $2 \%$ of Arts Council money, is almost the lowest per capita amongst OECD countries. The Australian Council spends around 13\%, the Arts 
Council of Great Britain, some 14\%; support for Scottish Opera, serving a similar population to New Zealand's in 1989-90 was around \$10 million. Funds for opera are usually comparable to those for a symphony orchestra (NZSO \$8.4 million), to a ballet company (Royal New Zealand Ballet, some $\$ 1$ million and a similar amount to the Ballet School), and they are usually well over $50 \%$ of the company's budget. Thus, assessed by even the most modest criteria, opera grants should total well over $\$ 1$ million.

In other countries opera holds the pivotal place in the performing arts, calling on all theatrical, dance and music disciplines as well as those of the visual arts. New Zealand's penurious policy holds opera in a double bind. When two-thirds of the costs have to be met from the box office, seat prices have to be high. When companies never have an opportunity to build up reserves and have no outside guarantees they cannot risk departing from the safest repertoire. As a result New Zealand audiences remain conservative, because of the exclusiveness engendered by high ticket prices

Barry Mora (il Conta de Luna) and Flora Edwards (Azucena) in Wellington City Opera's critically acclaimed production of Il Trovatore, at the State Opera House, June 1991 and because no-one will dare to perform anything in the least adventurous. This reinforces the inane slur of elitism and even allows elements in the Arts Council to attack opera companies for being conservative. There can be no Baroque opera, no less-familiar or largerscale Verdi, no Berlioz or Wagner, no Janacek, no Britten, no Strauss, let alone New Zealand opera. The present situation forces into exile a growing number of gifted young New Zealand singers whose predecessors now people the opera houses of Australia, Europe and elsewhere.

For opera is a universal art. It does not have a racial or sectarian label attached to it. It is not to be denigrated because it emerged from social classes that had power and wealth any more than we need to dismiss great Renaissance art because it was produced for a profligate and corrupt Papacy or the courts of autocrats. It is saddening to hear otherwise well-informed people parroting half-understood racist concepts about the kinds of art that are relevant to New Zealanders. Are they not suggesting a second-class status for those who are to be sheltered from the greatest and most universal of the performing arts? Opera everywhere is exciting growing numbers of people of all ages, colours and politics.

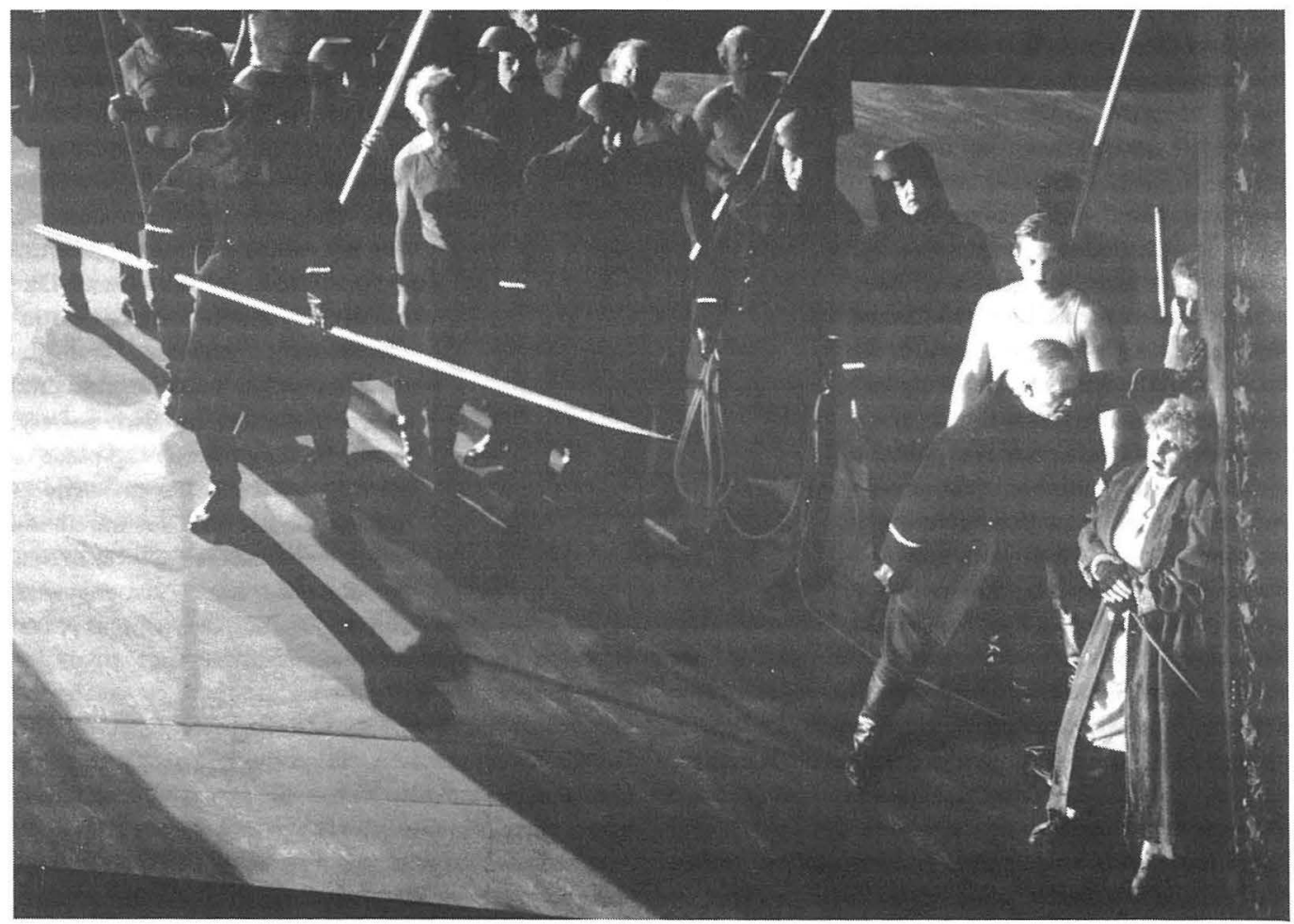

